Jurnal Sulolipu : Media Komunikasi Sivitas Akademika dan Masyarakat

Vol. 21 No.12021

e-issn: 2622-6960, p-issn : 0854-624X

\title{
KONDISI FISIK RUMAH DAN RIWAYAT KONTAK PENDERITA KAITANNYA DENGAN KEJADIAN KUSTA
}

\author{
Physical Condition Of The House And History Of Contact With The Patient Related To The Event \\ Of Leprosy \\ Indah Nur Wahyuni ${ }^{1}$, Nur Haidah ${ }^{2}$, Winarko ${ }^{3}$ \\ 1, 3 Poltekkes Kemenkes Surabaya \\ 2 Poltekkes Kemenkes Makassar \\ *Email : indahnwahyuni24@gmail.com, nurhaidah2@gmail.com
}

\begin{abstract}
Mycobacterium leprae is the germ that causes leprosy. The mode of transmission of leprosy is through the upper respiratory tract and through prolonged skin contact. Indonesia is in third place after eelndia and Brazil in donating leprosy patients in the world. The physical condition of the house that does not meet health requirements such as ventilation, residential density, humidity can be a medium for transmitting leprosy. The purpose of this study was to determine the relationship between the physical condition of the house and history of contact with the incidence of leprosy (Case Study of Leprosy Patients at RSK Sumber Glagah, Mojokerto Regency). This study used an analytical observational method with a case control approach. Data was collected by interview and observation using observation sheets. The population in this study were 20 people with leprosy and a sample of 19 people with leprosy and 19 controls were taken. The data obtained were then analyzed analytically using the chi-square test. The results of the bivariate analysis showed a relationship between the physical condition of the house and history of contact with the incidence of leprosy, namely ventilation ( $p$-value $=0.003)$, humidity ( $p$-value $=0.001)$, lighting $(p$-value $=0.000)$, occupancy density ( $p$ value $=0.000)$, and contact history ( $p v a l u e=0.000)$. Based on these statistical tests, it can be concluded that there is a proven relationship between ventilation, humidity, lighting, occupancy density, and a history of contact with the incidence of leprosy. transmission of leprosy.

Keywords: Leprosy Incidence, Sumber Glagah Hospital, Physical Condition of the House, and Contact History
\end{abstract}

\begin{abstract}
ABSTRAK
Mycobacterium Leprae merupakan kuman penyebab penyakit Kusta. Cara penularan penyakit kusta yaitu melalui saluran pernapasan bagian atas dan melalui kontak kulit yang lama. Indonesia berada di urutan ketiga setelah eelndia dan Brazil dalam menyumbangkan pasien kusta di dunia. Kondisi fisik rumah yang tidak memenuhi persyaratan kesehatan seperti ventilasi, kepadatan hunian, kelembaban dapat menjadi media penularan penyakit kusta. Tujuan penelitian ini yaitu untuk mengetahui hubungan kondisi fisik rumah dan riwayat kontak dengan kejadian kusta (Studi Kasus Penderita Kusta di RSK Sumber Glagah, Kabupaten Mojokerto).Penelitian ini menggunakan metode observasional analitik dengan pendekatan case control. Pengumpulan data dilakukan dengan wawancara dan observasi menggunakan lembar observasi. Populasi dalam penelitian ini sebanyak 20 penderita kusta dan diambil sampel sebanyak 19 penderita kusta dan 19 kontrol. Data yang diperoleh selanjutnya dianalisis secara analitik menggunakan uji chi-square. Hasil analisis bivariat adanya hubungan antara kondisi fisik rumah dan riwayat kontak dengan kejadian kusta yaitu ventilasi ( $p$ value $=0.003$ ), kelembaban $(p v a l u e=0.001$ ), pencahayaan ( pvalue $=0.000)$, kepadatan hunian ( pvalue $=0.000)$, dan riwayat kontak $(p v a l u e=0.000)$. Berdasarkan uji statistik tersebut dapat disimpulkan bahwa terbukti ada hubungan antara ventilasi, kelembaban, pencahayaan, kepadatan hunian, dan riwayat kontak dengan kejadian kusta.Disarankan kepada masyarakat untuk meningkatkan perilaku hidup bersih dan sehat khususnya dengan membiasakan membuka jendela ketika pagi dan siang hari untuk mencegah terjadinya penularan penyakit kusta.
\end{abstract}

Kata kunci: Kejadian Kusta, RSK Sumber Glagah, Kondisi Fisik Rumah, dan Riwayat Kontak

\section{PENDAHULUAN}

Rumah merupakan kebutuhan yang penting bagi manusia sebagai tempat untuk berlindung. Rumah yang sehat ditandai dengan rumah yang bebas dari gangguan kesehatan lahir, batin dan sosial. Menurut Kepmenkes RI No.829/MENKES/SK/VII/1999 tentang Persyaratan Kesehatan Perumahan, bahwa rumah sehat adalah rumah yang memenuhi persyaratan yaitu rumah yang memiliki luas ventilasi minimal $10 \%$ dari luas lantai, intensitas pencahayaan minimal 60 lux, kelembaban yaitu antara $40 \%$ - 70\%, serta kepadatan hunian minimal $8 \mathrm{~m}^{2}$ yang tidak dihuni lebih dari 2 orang kecuali anak berusia kurang dari 5 tahun. Jumnlah Penderita Kusta yang dilaporkan tahun 2013 sebanyak 71 kasus MBdan PB, laki-laki senayak 44 orang dan perempuan sebanyak 27 orang, dengan angka prevalensi per 10.000 penduduk adlah 0,75 (Profil Kesehatan Kabupaten Mojokerto 2013).

Menurut Andita (2017) menjelaskan bahwa terdapat hubungan antara rumah yang memiliki lingkungan sehat dengan kejadian kusta di Kabupaten Sampang. Hal tersebut dikarenakan rumah yang diteliti sebagian besar memiliki jendela ruang keluarga namun jarang dibuka, sebagian besar tidak memiliki jendela kamar 
Jurnal Sulolipu : Media Komunikasi Sivitas Akademika dan Masyarakat

Vol. 21 No.12021

e-issn: 2622-6960, p-issn : 0854-624X

dikarenakan rumah tersebut terbuat dari seng, serta keadaan dalam rumah yang gelap karena kurangnya cahaya matahari yang masuk ke dalam rumah.

Kusta adalah penyakit menular yang disebabkan oleh mycobacterium leprae yang mana dapat ditularkan melalui saluran pernapasan dan kontak kulit dalam waktu yang lama. Penyakit kusta dapat menyerang berbagai organ tubuh manusia kecuali susunan saraf pusat (Depkes RI, 2007). Apabila penyakit ini tidak segera ditangani maka dapat menyebabkan kerusakan kulit saraf, mata bahkan dapat menimbulkan kecacatan terhadap penderita. Indonesia berada di urutan ketiga setelah India dan Brazil dalam menyumbangkan pasien kusta di dunia. Penyakit kusta adalah penyakit menular yang dapat menimbulkan masalah baik dari segi medis, sosial, ekonomi, budaya, keamanan dan ketahanan nasional. Penyakit kusta sejak dahulu sampai sekarang ditakuti oleh masyarakat, keluarga maupun petugas kesehatan. Hal tersebut disebabkan karena kurangnya pengetahuan tentang penyakit kusta dan adanya kepercayaan yang salah terhadap kusta dan cacat yang ditimbulkannya (Firdaus, 2019).

Kegiatan studi pendahuluan dilakukan oleh peneliti di wilayah kerja RSK Sumber Glagah. RSK Sumber Glagah adalah UPT (Unit Pelaksana Teknis) Kesehatan Provinsi Jawa Timur yang memberikan layanan pengobatan kusta. Dari studi pendahuluan yang peneliti lakukan didapatkan hasil bahwa terdapat 20 penderita kusta yang berobat di Rumah Sakit tersebut. Dari 20 penderita tersebut peneliti melakukan studi pendahuluan pada 5 rumah penderita yang mana didapatkan hasil bahwa kelima rumah tersebut memiliki kualitas kondisi fisik rumah yang belum memenuhi persyaratan, yaitu ventilasi yang tidak memenuhi syarat karena luas ventilasi $<10 \%$ dari luas lantai, kepadatan hunian kurang memenuhi syarat karena luas kamar kurang dari $8 \mathrm{~m}^{2}$ dan dihuni lebih dari 2 orang, pencahayaan kurang memenuhi syarat karena intensitas cahaya alami kurang dari 60 lux, dan kelembaban kurang memenuhi syarat karena lebih dari $70 \%$. Selain itu, 3 dari 5 penderita pernah melakukan kontak fisik dan non fisik dengan penderita kusta dalam kurun waktu $>2$ tahun.

\section{METODE PENELITIAN}

Jenis penelitian bersifat observasional analitik dengan pendekatan case control study. Lokasi penelitian dilakukan di rumah penderita kusta dan di rumah non penderita kusta di wilayah kerja RSK Sumber Glagah, Mojokerto. Teknik pengambilan sampel. Teknik pengambilan sampel dengan simple random sampling. Populasi dalam penelitian ini sebanyak 20 penderita kusta dan diambil sampel sebanyak 19 penderita kusta dan 19 kontrol.Kriteria inklusi adalah pasien yang berobat November 2019 - Mei 2020.Variabel bebas terdiri dari luas ventilasi, kelembaban, intensitas pencahayaan, kepadatan hunian, dan riwayat kontak. Variabel terikat yaitu kejadian kusta. Data yang diperoleh selanjutnya dianalisis secara analitik menggunakan uji chisquare.

\section{HASIL DAN PEMBAHASAN}

\section{Hubungan Ventilasi dengan Kejadian Kusta}

\begin{tabular}{|c|c|c|c|c|c|c|}
\hline \multirow{4}{*}{ No } & \multirow{4}{*}{$\begin{array}{l}\text { Ventilasi } \\
\text { Rumah }\end{array}$} & \multicolumn{5}{|c|}{$\begin{array}{l}\text { Tabel } 1 \\
\text { is Bivariat Antara Ventilasi } \\
\text { an Kejadian Penyakit Kusta } \\
\text { Tahun } 2020\end{array}$} \\
\hline & & \multicolumn{4}{|c|}{ Kejadian Penyait Kusta } & \multirow{3}{*}{$\begin{array}{l}\text { uji Chi- } \\
\text { square }\end{array}$} \\
\hline & & \multicolumn{2}{|c|}{ Kasus } & \multicolumn{2}{|c|}{ Kontrol } & \\
\hline & & N & $\%$ & $\mathrm{~N}$ & $\%$ & \\
\hline 1 & $\begin{array}{l}\text { Tidak } \\
\text { Memenuhi } \\
\text { Syarat }\end{array}$ & 16 & 84,2 & 6 & 31,6 & \multirow{3}{*}{$\begin{array}{l}\text { pvalue }= \\
0,001\end{array}$} \\
\hline 2 & $\begin{array}{c}\text { Memenuhi } \\
\text { Syarat }\end{array}$ & 3 & 15,8 & 13 & 68,4 & \\
\hline & Jumlah & 19 & 100 & 19 & 100 & \\
\hline
\end{tabular}

Hasil penelitian menunjukkan bahwa rumah responden dengan ventilasi yang tidak memenuhi syarat berjumlah 16 rumah $(84,2 \%)$ pada kelompok kasus, sedangkan 6 rumah $(31,6 \%)$ pada kelompok kontrol. Rumah responden dengan ventilasi memenuhi syarat bejumlah 3 rumah $(15,8 \%)$ pada kelompok kasus, sedangkan ada 13 rumah $(68,4 \%)$ pada kelompok kontrol.

Dari hasil penelitian dengan menggunakan uji Chi-square menunjukkan bahwa ventilasi memiliki nilai pvalue sebesar $0,001<\alpha(0,05)$, yang berarti ada hubungan 
Jurnal Sulolipu : Media Komunikasi Sivitas Akademika dan Masyarakat

Vol. 21 No.12021

e-issn: 2622-6960, p-issn : 0854-624X

antara ventilasi rumah dengan kejadian penyakit kusta.

Adanya hubungan antara luas ventilasi dengan kejadian kusta disebabkan karena ketika peneliti melakukan observasi, rumah penderita memiliki ventilasi namun tidak difungsikan sebagaimana mestinya, misalnya ventilasi harus dibuka ketika pagi matahari yang masuk ke dalam rumah namun pemilik rumah menutupnya dan membiarkan berdebu. Hal ini sejalan dengan penelitian yang dilakukan oleh Sya'diana (2018) bahwa terdapat hubungan antara luas ventilasi dengan kejadian kusta di Wilayah Kerja Puskesmas Sukorejo Kabupaten Ponorogo karena dalam penelitiannya kebanyakan warga yang menderita kusta tidak rutin membuka jendela, hanya sebesar 13,3\% yang rutin membuka jendela. Selain itu sebagian besar rumah responden yang diteliti memiliki ventilasi hanya pada ruang tamu dan juga sebagian reponden memakai jendela yang permanen sehingga sirkulasi udara menjadi terhambat dan udara segar tidak dapat masuk kedalam ruangan. Selain itu, penelitian yang dilakukan oleh Rhomdani et al., (2020) menunjukkan bahwa luas ventilasi berhubungan dengan kejadian kusta di wilayah kerja Puskesmas Talango Kabupaten Sumenep. Dalam hasil penelitiannya menyatakan bahwa responden kasus memiliki ruang tidur yang tidak memenuhi persyaratan luas ventilasi yaitu $<10 \%$ dari luas lantai. Luas ventilasi yang tidak memenuhi persyaratan kesehatan dapat menyebabkan ruang tidur menjadi lembab sehingga menimbulkan berbagai mikroorganisme dapat tumbuh subur khususnya bakteri mycobacterium leprae. Penelitian yang sama juga dilakukan oleh Lathifah et al., (2020) bahwa 11 dari 12 rumah responden kasus memiliki luas ventilasi tidak memenuhi syarat yaitu $<10 \%$ dari luas lantai. Hal tersebut dapat menyebabkan kurangnya pergantian udara di dalam rumah sehingga rumah menjadi pengap dan lembab.

\section{Hubungan Kelembaban dengan Kejadian Kusta}

Tabel 2

Hasil Analisis Bivariat Antara Kelembaban Rumah dengan Kejadian Kusta Tahun 2020

\begin{tabular}{cccccccc}
\hline & \multicolumn{5}{c}{$\begin{array}{c}\text { Kejadian Penyakit } \\
\text { Kusta }\end{array}$} \\
\cline { 3 - 7 } No & $\begin{array}{c}\text { Kelem- } \\
\text { baban } \\
\text { Rumah }\end{array}$ & \multicolumn{2}{c}{ Kasus } & \multicolumn{2}{c}{ Kontrol } & $\begin{array}{c}\text { uji Chi- } \\
\text { square }\end{array}$ \\
& $\begin{array}{c}\text { Tidak } \\
\text { 1. }\end{array}$ & $\mathrm{N}$ & $\%$ & $\mathrm{~N}$ & $\%$ & \\
\hline & $\begin{array}{c}\text { Memenuhi } \\
\text { Syarat }\end{array}$ & 17 & 89,5 & 6 & 31,6 & $\begin{array}{c}\text { pvalue }= \\
0,000\end{array}$ \\
\hline & $\begin{array}{c}\text { Memenuhi } \\
\text { Syarat }\end{array}$ & 2 & 10,5 & 13 & 68,4 & \\
\hline & Jumlah & 19 & 100 & 19 & 100 & \\
\hline
\end{tabular}

Hasil penelitian menunjukkan bahwa rumah responden yang memiliki kelembaban tidak memenuhi syarat berjumlah 17 rumah $(89,5 \%)$ pada kelompok kasus, sedangkan 6 rumah $(31,6 \%)$ pada kelompok kontrol. Rumah responden yang memiliki kelembaban memenuhi syarat berjumlah 2 rumah (10,5\%) pada kelompok kasus, sedangkan 13 rumah $(68,4 \%)$ pada kelompok kontrol.

Dari hasil penelitian dengan menggunakan uji Chi-square menunjukkan bahwa kelembaban memiliki nilai pvalue sebesar $0,000<\alpha(0,05)$, yang berarti ada hubungan antara kelembaban rumah dengan penyakit kusta.

Adanya hubungan antara kelembaban rumah dengan kejadian kusta dikarenakan rumah penderita kusta berukuran kecil, memiliki pencahayaan yang kurang, dan tidak memiliki luas ventilasi yang memenuhi syarat yaitu minimal $10 \%$ dari luas lantai sehingga keadaan kamar penderita kusta menjadi lembab. Rumah yang terlalu lembab maka akan menyebabkan terjadinya pertumbuhan dan perkembangan mikroorganisme patogen salah satunya adalah kuman mycobacterium leprae. Hal ini sejalan dengan penelitian yang dilakukan oleh Sya'diana (2018) menyimpulkan bahwa responden yang memiliki kelembaban tidak memenuhi persyaratan rumah sehat yaitu $40 \%$ $70 \%$ dapat meningkatkan resiko terjadinya penyakit kusta daripada responden yang memiliki kelembaban rumah yang memenuhi persyaratan. Selain itu penelitian yang dilakukan oleh Saleh et al., (2019) yang dilakukan di Kabupaten Jeneponto mengatakan bahwa kelembaban yang $<40 \%$ dan $>70 \%$ dapat 
Jurnal Sulolipu : Media Komunikasi Sivitas Akademika dan Masyarakat

Vol. 21 No.12021

e-issn: 2622-6960, p-issn : 0854-624X

meningkatkan resiko terjadinya penyakit kusta. Kelembaban ruangan dapat dipengaruhi oleh kurangnya luas ventilasi rumah sehingga tidak ada pertukaran udara di dalam rumah. Penelitian juga dilakukan oleh Prasetyaningtyas (2017) yang menyimpulkan bahwa kelembaban rumah yang tidak memenuhi syarat dapat menyebabkan pengaruh buruk terhadap kesehatan penghuninya salah satunya adalah terjadinya penyakit kusta.

\section{Hubungan Intensitas Pencahayaan dengan Kejadian Kusta}

\section{Tabel 3}

Hasil Analisis Bivariat Antara Pencahayaan Rumah dengan Kejadian Kusta Tahun 2020

\begin{tabular}{|c|c|c|c|c|c|c|}
\hline \multirow{3}{*}{ No } & \multirow{3}{*}{$\begin{array}{l}\text { Pencahayaan } \\
\text { Rumah }\end{array}$} & \multicolumn{4}{|c|}{$\begin{array}{l}\text { Kejadian Penyakit } \\
\text { Kusta }\end{array}$} & \multirow{3}{*}{$\begin{array}{c}\text { uji } \\
\text { Chi- } \\
\text { square }\end{array}$} \\
\hline & & \multicolumn{2}{|c|}{ Kasus } & \multicolumn{2}{|c|}{ Kontrol } & \\
\hline & & $\mathrm{N}$ & $\%$ & $\mathrm{~N}$ & $\%$ & \\
\hline 1 & $\begin{array}{l}\text { Tidak } \\
\text { Memenuhi } \\
\text { Syarat }\end{array}$ & 18 & 94,7 & 3 & 15,8 & $\begin{array}{l}\text { pvalue }= \\
0,000\end{array}$ \\
\hline 2 & $\begin{array}{l}\text { Memenuhi } \\
\text { Syarat }\end{array}$ & 1 & 5,3 & 16 & 84,2 & \\
\hline & Jumlah & 19 & 100 & 19 & 100 & \\
\hline
\end{tabular}

Hasil penelitian menunjukkan bahwa rumah responden dengan pencahayaan yang tidak memenuhi syarat berjumlah 18 rumah (94,7\%) pada kelompok kasus, sedangkan 3 rumah $(15,8 \%)$ pada kelompok kontrol. Rumah responden yang memiliki pencahayaan memenuhi syarat berjumlah 1 rumah $(5,3 \%)$ pada kelompok kasus, sedangkan 16 rumah $(84,2 \%)$ pada kelompok kontrol.

Dari hasil penelitian dengan menggunakan uji Chi-square menunjukkan bahwa pencahayaan memiliki nilai pvalue sebesar $0,000<\alpha(0,05)$, yang berarti ada hubungan antara pencahayaan rumah dengan penyakit kusta.

Adanya hubungan antara intensitas
pencahayaan dengan kejadian kusta dikarenakan rumah penderita kusta sebagian besar gelap meskipun telah memakai pencahayaan buatan dan pemilik rumah tidak membuka jendelanya ketika pagi dan siang hari sehingga cahaya matahari tidak dapat masuk ke dalam rumah. Hasil penelitian ini sejalan dengan penelitian yang dilakukan oleh Efrizal et al.,
(2016) di Yogyakarta bahwa pencahayaan rumah penderita kusta terlihat gelap yaitu $<60$ lux. Hal tersebut dikarenakan sebagian besar tidak memiliki ventilasi dan tidak menggunakan genteng kaca sehingga sinar matahari tidak dapat masuk ke dalam rumah. Penelitian yang dilakukan oleh Idayani et al., (2017) bahwa kurangnya cahaya yang masuk ke dalam rumah dapat menyebabkan ruangan menjadi lembab sehingga bakteri mycobacterium leprae dapat tumbuh subur. Penelitian juga dilakukan oleh Rhomdani et al., (2020) bahwa seseorang yang tinggal di dalam rumah yang tidak mendapatkan pencahayaan alami yang cukup berpeluang menderita kusta sebesar 3,69 kali lebih besar daripada seseorang yang tinggal di dalam rumah dengan pencahayaan alami yang cukup yaitu minimal sebesar 60 lux.

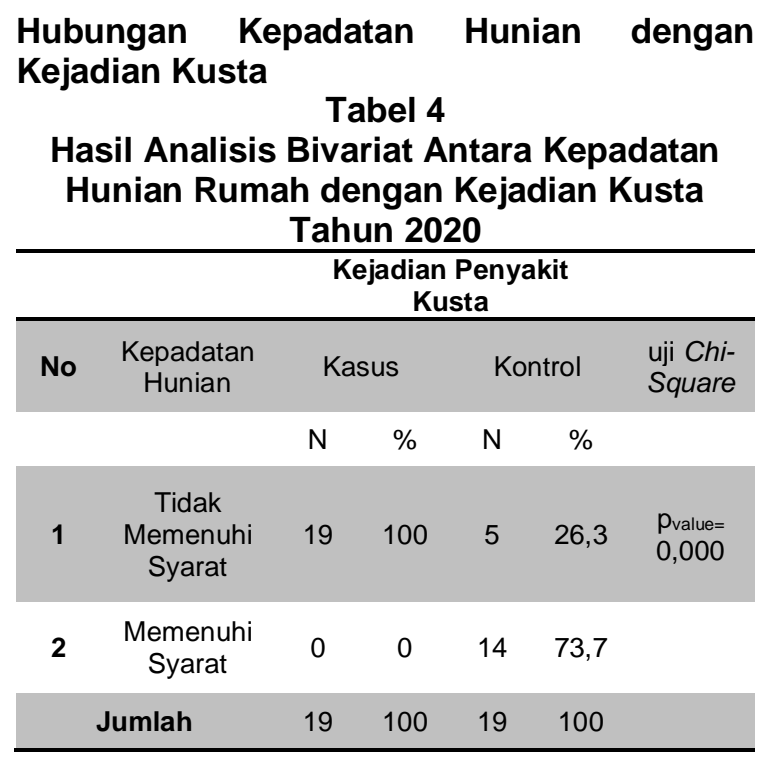

Hasil penelitian menunjukkan bahwa rumah responden dengan kepadatan hunian yang tidak memenuhi syarat berjumlah 19 rumah $(100 \%)$ pada kelompok kasus, sedangkan 5 rumah $(26,3 \%)$ pada kelompok kontrol. Rumah responden dengan kepadatan hunian yang memenuhi syarat berjumlah 0 rumah $(0 \%)$ pada kasus, sedangkan pada kelompok kontrol berjumlah 14 rumah $(73,7 \%)$.

Berdasarkan hasil penelitian dengan menggunakan uji Chi-Square menunjukkan bahwa kepadatan hunian memiliki nilai pvalue sebesar $0,000<\alpha(0,05)$, maka ada hubungan antara kepadatan hunian rumah dengan penyakit kusta. 
Jurnal Sulolipu : Media Komunikasi Sivitas Akademika dan Masyarakat

Vol. 21 No.12021

e-issn: 2622-6960, p-issn : 0854-624X

Adanya hubungan antara kepadatan hunian dengan kejadian kusta dikarenakan kamar penderita kusta yang telah dilakukan pengukuran memiliki luas sebesar $<8 \mathrm{~m}^{2}$ dan dihuni lebih dari 2 orang. Hal tersebut tidak sesuai dengan Keputusan Menteri Kesehatan Republik Indonesia Nomor 829/MENKES/VII/1999 tentang Persyaratan Kesehatan Perumahan bahwa luas ruang tidur minimal $8 \mathrm{~m}^{2}$ yang dianjurkan digunakan tidak lebih dari 2 orang kecuali anak yang berusia kurang dari 5 tahun. Sya'diana, U. (2018) mengemukan bahwa apabila terjadi kepadatan hunian di dalam rumah maka dapat menyebabkan mudahnya penularan penyakit yang terjadi di dalam rumah khususnya penyakit kusta yang dapat ditularkan melalui saluran pernapasan bagian atas dan melalui kontak kulit yang lama karena kemungkinan kontak antar anggota keluarga akan lebih besar dan sering. Penelitian ini sejalan dengan penelitian yang dilakukan oleh Siswanti et al., (2018), bahwa ada hubungan antara kepadatan hunian kamar dengan kejadian kusta di wilayah kerja Puskesmas Bandarharjo, Semarang. Kepadatan hunian kamar yang tidak memenuhi syarat kesehatan yaitu luas kamar dengan ukuran $8 \mathrm{~m}^{2}$ tidak dihuni lebih dari 2 orang kecuali anak yang berusia dibawah 5 tahun dapat meningkatkan terjadinya kontak baik itu kontak fisik maupun non fisik antara individu satu dengan yang lain sehingga dapat mempermudah penularan penyakit kusta. Selain itu, dalam penelitian yang dilakukan oleh Aprizal et al., (2017) di Kabupaten Lamongan menyatakan bahwa kelompok kasus (51,76\%) sebagian besar tinggal di rumah yang padat penghuni dan pada kelompok kontrol $(77,65 \%)$ tinggal di rumah yang tidak padat penghuni. Hal ini menunjukkan bahwa kepadatan hunian dapat meningkatkan risiko terjadinya penularan penyakit kusta. Penelitian yang sama juga dilakukan oleh Siswanti et al., (2018) bahwa kepadatan hunian yang tidak memenuhi syarat dapat menyebabkan meningkatnya kontak antar individu satu dengan individu yang lain yang ada di dalam rumah baik kontak fisik maupun non fisik yang dapat mempermudah terjadinya penularan penyakit kusta.

\section{Hubungan Riwayat Kontak dengan Kejadian Kusta}

\section{Tabel 5 \\ Hasil Analisis Bivariat Antara Riwayat Kontak dengan Kejadian Kusta Tahun 2020}

\begin{tabular}{|c|c|c|c|c|c|c|}
\hline \multirow{3}{*}{ No } & \multirow{3}{*}{$\begin{array}{l}\text { Riwayat } \\
\text { Kontak }\end{array}$} & \multicolumn{4}{|c|}{$\begin{array}{c}\text { Kejadian Penyakit } \\
\text { Kusta }\end{array}$} & \multirow{3}{*}{$\begin{array}{l}\text { uji Chi- } \\
\text { Square }\end{array}$} \\
\hline & & \multicolumn{2}{|c|}{ Kasus } & \multicolumn{2}{|c|}{ Kontrol } & \\
\hline & & $\mathrm{N}$ & $\%$ & $\mathrm{~N}$ & $\%$ & \\
\hline 1. & Kontak & 17 & 89,5 & 2 & 10,5 & $\begin{array}{l}P_{\text {value }}= \\
0,000\end{array}$ \\
\hline 2. & $\begin{array}{l}\text { Tidak } \\
\text { Kontak }\end{array}$ & 2 & 10,5 & 17 & 89,5 & \\
\hline & umlah & 19 & 100 & 19 & 100 & \\
\hline
\end{tabular}

Hasil penelitian menunjukkan bahwa responden yang memiliki riwayat kontak dengan penderita kusta berjumlah 17 responden $(89,5 \%)$ pada kasus, sedangkan pada kelompok kontrol berjumlah 2 responden (10,5\%). Responden yang tidak memiliki riwayat kontak dengan penderita kusta berjumlah 2 responden (10,5\%) pada kelompok kasus, sedangkan 17 responden (89,5\%) pada kelompok kontrol.

Berdasarkan hasil penelitian dengan menggunakan uji Chi-Square menunjukkan bahwa riwayat kontak memiliki nilai pvalue sebesar $0,000<\alpha(0,05)$, maka ada hubungan antara riwayat kontak dengan penyakit kusta.

Adanya hubungan antara riwayat kontak dengan kejadian kusta dikarenakan responden pada kelompok kasus banyak yang memiliki riwayat kontak dengan penderita kusta sebelumnya dalam waktu yang lama yaitu lebih dari 2 tahun baik itu kontak secara fisik maupun non fisik dan baik kontak pada orang serumah maupun orang yang tidak serumah. Hal ini sejalan dengan penelitian yang dilakukan oleh Gustam et al., (2017), menunjukkan bahwa ada hubungan antara riwayat kontak dengan kejadian kusta yang terjadi di Kecamatan Kenjeran, Kecamatan Semampir dan Kecamatan Tandes. Sebanyak 74,3\% responden penderita kusta pernah melakukan interaksi kontak lebih dari 2 tahun baik pada orang serumah maupun pada orang yang tidak serumah seperti tetangga, rekan kerja, maupun teman. Dalam hal ini berarti seseorang yang memiliki riwayat kontak dalam waktu yang lama yaitu lebih dari 2 tahun dapat memperbesar risiko terjadinya penularan kusta baik itu melalui 
Jurnal Sulolipu : Media Komunikasi Sivitas Akademika dan Masyarakat

Vol. 21 No.12021

e-issn: 2622-6960, p-issn : 0854-624X

kontak langsung maupun tidak langsung. Menurut Harlim et al., (2019) menjelaskan bahwa terdapat hubungan antara riwayat kontak dengan kejadian kusta di RSK Dr. Sitanala Provinsi Banten. Orang yang sebelumnya memiliki riwayat kontak yang dekat baik kontak fisik maupun non fisik dan terjadi secara terus menerus dalam waktu yang lama yaitu lebih dari 2 tahun memiliki risiko lebih besar tertular penyakit kusta bila dibandingkan dengan orang yang memiliki riwayat kontak kurang dari 2 tahun. Penelitian yang sama juga dilakukan oleh Nuraeni (2018) bahwa riwayat kontak merupakan salah satu faktor risiko terjadinya penularan penyakit kusta pada anak di kota Surabaya. Terjadinya kontak serumah antar anggota keluarga baik itu tidur bersama dengan penderita maupun tidur secara bersama-sama sekeluarga di dalam satu ruangan dapat berpotensi terjadinya penularan penyakit kusta yang semakin besar. Selain itu, menurut Rodrigues et al., (2019) menyimpulkan bahwa faktor yang mempengaruhi terjadinya kusta anak yang terjadi di daerah endemik kusta di Mato Grosso, Brazil salah satunya adalah adanya riwayat kontak dengan salah satu anggota keluarga yang menderita penyakit kusta dengan lama tinggal $\geq 5$ tahun. Penularan tidak terbatas hanya pada riwayat kontak dengan keluarga yang terinfeksi kusta namun juga mencakup kontak pada tetangga, teman, maupun rekan kerja. Semakin banyak anggota keluarga yang menderita kusta serta didukung dengan kondisi fisik rumah yang tidak sehat seperti kurangnya ventilasi udara dalam rumah, pencahayaan rumah yang gelap yaitu $<60$ lux, rumah yang lembab maka akan semakin besar pula risiko terjadinya penularan kusta.

\section{KESIMPULAN DAN SARAN}

Berdasarkan hasil penelitian dapat ditarik kesimpulan bahwa ada hubungan antara ventilasi, kelembaban, pencahayaan, kepadatan hunian, dan riwayat kontak dengan kejadian kusta.

Bagi masyarakat diharapkan dapat melakukan penyehatan kondisi fisik rumah untuk mencegah penularan penyakit kusta, khususnya dengan membiasakan membuka jendela rumah ketika pagi dan siang hari agar terjadi pertukaran udara dari dalam ke luar rumah dan menambah genteng kaca untuk rumah yang sudah memiliki genteng kaca atau memasang genteng kaca untuk rumah yang belum memiliki genteng kaca agar cahaya matahari dapat masuk ke dalam rumah.

\section{DAFTAR PUSTAKA}

Andita, U. (2017). Hubungan Rumah Sehat dan Karakteristik Individu dengan Kasus Kusta di Wilayah Kerja Puskesmas Kedungdung Kecamatan Kedungdung Kabupaten Sampang. Fakultas Kesehatan Masyarakat Universitas Airlangga.

Aprizal, Lazuardi, L., \& Soebono, H. (2017). Faktor Risiko Kejadian Kusta di Kabupaten Lamongan Risk Factors of Leprosy in District of Lamongan. Berita Kedokteran Masyarakat (BKM Journal of Community Medicine and Public Health), 33(9), 427-432.

Depkes, RI. (2007). Buku Panduan Pelaksanaan Program P2 Kusta Bagi Petugas Unit Pelayanan Kesehatan. Jakarta: Direktorat Jenderal Pengendalian Penyakit dan Penyehatan Lingkungan.

Efrizal, E., Lazuardi, L., \& Seobono, H. (2016). Faktor Risiko dan Pola Distribusi Kusta di Yogyakarta. Berita Kedokteran Masyarakat, 32(10), 347-352.

Firdaus, F. (2019). Risiko keterlambatan berobat dan reaksi kusta dengan cacat tingkat 2. Jurnal Berkala Epidemiologi. https://doi.org/10.20473/jbe.v7i1.25-32

Gustam, T. Y. P., Agusni, I., \& Nuswantoro, D. (2017). Hubungan antara Riwayat Kontak dengan Kejadian Kusta Multibasiler. The 6th University Research Colloquium 2017, 37. Retrieved from http://journal.ummgl.ac.id/index.php/urecol/article/view/893

Harlim, A., Yulia, H. C., \& Suci, A. M. (2019). Relation Between Contact History And Bacille CalmetteGuerin (BCG) Vaccination Status With Leprosy Case In Dr. Sitanala Hospital. International 
Jurnal Sulolipu : Media Komunikasi Sivitas Akademika dan Masyarakat

Vol. 21 No.12021

e-issn: 2622-6960, p-issn : 0854-624X

Journal of Recent Scientific Research, 10(5), 32535-32539. https://doi.org/10.24327/IJRSR

Idayani, T. N., Windraswara, R., \& Prameswari, G. N. (2017). Analisis Spasial Faktor Risiko Lingkungan dengan Kejadian Kusta di Wilayah Pesisir. HIGEIA (Journal of Public Health Research and Development), 1(4), 120-130. Retrieved from https://journal.unnes.ac.id/sju/index.php/higeia/article/view/15231

Kementerian Kesehatan RI No. 829 Tahun 1999. Tentang Persyaratan Kesehatan Perumahan.

Lathifah, N., \& Adriyani, R. (2020). Hubungan Lingkungan Fisik Rumah Dan Keberadaan Dna Mycobacterium Leprae Pada Sumber Air Dengan Kejadian Kusta Di Kecamatan Winongan Kabupaten Pasuruan Tahun 2018. 18(1), 32-37. https://doi.org/10.35882/jpk.v18i1.6

Latifah, N. (2018). Hubungan Karakteristik Individu, Personal Hygiene, dan Karakteristik Lingkungan dengan Kejadian Kusta di Kecamatan Winongan Kabupaten Pasuruan. Universitas Airlangga.

Nuraeni, T. (2018). Faktor Risiko Kejadian Kusta pada Anak di Kota Surabaya Tahun 2018. Jurnal Kesehatan Manarang, 4(1), 40. https://doi.org/10.33490/jkm.v4i1.55

Prasetyaningtyas, A. Y. (2017). Karakteristik, Kondisi Fisik Rumah dan Personal Hygiene Penderita Kusta. Higeia Journal of Public Health Research and Development.

Rhomdani, F., \& Sulistyorini, L. (2020). The Case of Leprosy in Work Area of Talango Health Center in Sumenep Regency: Case Control Study. Jurnal Kesehatan Lingkungan, 12(1), 21. https://doi.org/10.20473/jkl.v12i1.2020.21-29

Rodrigues, T. S. V., Gomes, L. C., Cortela, D. C. B., Silva, E. A., Silva, C. A. L., \& Ferreira, S. M. B. (2019). Factors Associated with Leprosy in Children Contacts of Notified Adults in an Endemic Region of Midwest Brazil. Jornal de Pediatria, (xx). https://doi.org/10.1016/j.jped.2019.04.004

Saleh, S., Wanci, R., \& Syahridha. (2019). Hubungan Kebersihan Lingkungan dan Kelembapan Udara dengan Kejadian Kusta di Kabupaten Jeneponto. Jurnal Keperawatan Muhammadiah, 221-224.

Sya'diana, U. (2018). Hubungan Kondisi Fisik Rumah dan Personal Hygiene dengan Kejadian Kusta di Wilayah Kerja Puskesmas Sukorejo Kabupaten Ponorogo. STIKES Bhakti Husada Mulia Madiun. 